\title{
High-resolution electrocardiography in dogs under doxorubicin-induced cardiomyopathy
}

[Eletrocardiografia de alta resolução em cães com cardiomiopatia induzida pela doxorrubicina]

\author{
W.L. Ferreira ${ }^{1}$, R.C.A. Sousa ${ }^{2}$, A.A. Camacho $^{3}$ \\ ${ }^{1}$ Curso de Medicina Veterinária - FOA-UNESP \\ Rua Clóvis Pestana, 793 \\ 160050-680 - Araçatuba, SP \\ ${ }^{2}$ Universidade Federal Rural de Pernambuco - Garanhuns, PE \\ ${ }^{3}$ Faculdade de Ciências Agrárias e Veterinárias - UNESP -- Jaboticabal, SP
}

\begin{abstract}
The occurrence of late potentials in dogs under doxorubicin-induced cardiomyopathy and their relationship with the development of ventricular arrhythmias or sudden death were studied. Seven adult mongrel dogs of both sexes were used. Cardiomyopathy was induced by slow intravenous infusion of doxorubicin $\left(30 \mathrm{mg} / \mathrm{m}^{2}\right)$ at 21 -day intervals, until a total cumulative dose of $240 \mathrm{mg} / \mathrm{m}^{2}$ was reached. Animals were monitored by echocardiography. After the induction of cardiomyopathy, high-resolution electrocardiography was recorded. Late potentials were observed in two animals that suddenly died a few days later.
\end{abstract}

Keywords: dog, high-resolution electrocardiography, late potential, doxorubicin

\section{RESUMO}

Determinaram-se a ocorrência de potencial tardio em cães com cardiomiopatia induzida pela doxorrubicina e sua relação com o desenvolvimento de arritmias ventriculares ou morte súbita. Sete cães adultos, sem raça definida, de ambos os sexos foram utilizados. A cardiomiopatia foi induzida por infusão venosa lenta de doxorrubicina $\left(30 \mathrm{mg} / \mathrm{m}^{2}\right)$ em intervalos de 21 dias, até uma dose total cumulativa de $240 \mathrm{mg} / \mathrm{m}^{2}$. Os animais foram monitorados ecocardiograficamente. Após a confirmação da cardiomiopatia, foi feito o registro da eletrocardiografia de alta resolução. Potenciais tardios foram observados em dois animais que morreram subitamente poucos dias após.

Palavras-chave: cão, eletrocardiografia de alta resolução, potencial tardio, doxorrubicina

\section{INTRODUCTION}

Cardiac arrhythmias are heart rhythm disorders commonly diagnosed in patients with cardiovascular disease (Jacobs, 1996).

High-resolution electrocardiography (HRECG) is a computerized method of recording late potentials, which can predict patients of ventricular tachycardia (Hatém et al., 1993). Late potentials are low-amplitude, high-frequency signals that occur in the terminal portion of the QRS complex or at the beginning of the ST segment. Such signals are related to the presence of fragmented and delayed electrical activity in the ventricles, and these potentials are undetectable by conventional electrocardiograms. It is a non-invasive method whose cost-benefit relation justifies its use in regular clinical evaluation. High-resolution electrocardiogram may contribute to the stratification of the risk of sudden death in dogs showing diseases related to the development of ventricular arrhythmias, or even when arrhythmias have already been detected.

Experimental models have helped the planning of diagnostic and therapeutic approaches for the control of ventricular arrhythmias. In this respect, the use of doxorubicin, an antibiotic isolated from Streptomyces peucetius var.

Recebido em 4 de setembro de 2007

Aceito em 2 de setembro de 2008

E-mail: wluis@fmva.unesp.br 
caesius, as an antineoplastic agent in human and veterinary oncology is limited due to its cytotoxic properties, which include the development of cumulative dose-related cardiomyopathy (Olson and Capen, 1977) that resembles the functional alterations produced by idiopathic dilated cardiomyopathy (Silva e Camacho, 2005; Pereira Neto et al., 2006).

Sudden death has been observed in dogs with idiopathic dilated cardiomyopathy, as well as in dogs showing other cardiomyopathies, conduction disturbances, congenital heart defects, endocrine diseases, and electrolytes imbalances (Strickland, 1998). The myocardial disease is considered to be among the most common cardiac diseases in dogs and mainly in large animals (Meurs, 2005). Its possible lifethreatening nature requires a more precise identification of patients which are at a high risk for these events.

The objective of the present study was to determine the risk of sudden death in dogs under doxorubicin-induced cardiomyopathy using HRECG.

\section{MATERIAL AND METHODS}

Seven healthy adult dogs of both sexes, averaging $20.9 \pm 6.5 \mathrm{~kg}$ b.w., were used. The animals were fed commercially available dog food $^{1}$ twice a day and water ad libitum. Dogs were chosen after clinic evaluation: physical examination, electrocardiogram, echocardiogram, and blood work (complete blood count and serum biochemistry). The study was approved by the Animal Care and Use Committee at the FCAV-UNESP.

Vials containing 50mg of lyophilized doxorubicin $^{2}$ were used for the induction of cardiomyopathy. Immediately before infusion, doxorubicin was diluted in $0.9 \%$ sterile saline to a final concentration of $2 \mathrm{mg} / \mathrm{ml}$.

The dogs were given doxorubicin $\left(30 \mathrm{mg} / \mathrm{m}^{2}\right)$ by slow intravenous infusion at 21-day intervals,

${ }^{1}$ Royal Canin ${ }^{\circledR}$ Size Nutrition: Medium Adult M25 - São Paulo, Brazil.

${ }^{2}$ Adriblastine ${ }^{\circledR}$ RD 50mg - Pharmacia \& Upjohn S.A. - St. Quentin em Yvelines, France. until a total cumulative dose of $240 \mathrm{mg} / \mathrm{m}^{2}$ was reached.

Prior to each administration of doxorubicin, the animals were submitted to an echocardiographic examination using an ultrasound apparatus ${ }^{3}$ equipped with a $5.0-\mathrm{MHz}$ transducer.

The animals were positioned in right lateral recumbency on a table with an opening on the surface. Electrodes were attached to each limb to allow simultaneous electrocardiographic recording. Generous coupling gel was applied to improve the sound wave conduction. The transducer was then positioned in the right parasternal window and two-dimensional images (B mode) were acquired. Cross-sectional images in the apical, papillary, cordal, mitral, and aortic planes and images in the longitudinal axis to evaluate the left ventricular outflow tract and to investigate the anatomical relationship, morphology, and functionality of the cardiac structures were recorded. Two-dimensionallyguided M-mode images were acquired for echocardiographic measurements. Using crosssectional images at the chordae tendineae level, the ultrasound beam was directed equidistant to the papillary muscles, and measurements of the left ventricular end-systolic and left-ventricular end-diastolic diameters were obtained. The fractional shortening and the ejection fraction were automatically calculated by the software of the equipment.

In addition to echocardiography, the animals were submitted to weekly physical examination and conventional computerized electrocardiography before each administration of doxorubicin until the final cumulative dose of $240 \mathrm{mg} / \mathrm{m}^{2}$.

Conventional computerized electrocardiography ${ }^{4}$ permitted the determination of heart rhythm and the duration and amplitude of the EKG waves and intervals in order to identify possible cardiac arrhythmias.

HRECG recordings were obtained after the cumulative dose of doxorubicin $\left(240 \mathrm{mg} / \mathrm{m}^{2}\right)$ was reached. The animals were kept awake (neither

${ }^{3} 300$ S Pandion Vet - Pie Medical - Maastricht, Netherlands. ${ }^{4}$ ECG-PC (version 2.10) - Tecnologia Eletrônica Brasileira São Paulo, Brazil. 
by the effect of tranquilization nor anesthesia) in a silent, dim-lit room. High-resolution electrocardiography was recorded using a digital holter system equipped with HRECG software ${ }^{5}$. Animals were maintained in left lateral recumbency and signals were obtained from the three orthogonal leads: X, Y, and Z. Lead X was positioned at the right (negative electrode) and left (positive electrode) fifth through sixth intercostal spaces at the junction of the upper and middle thirds of the thorax; lead Y was placed at the manubrium (negative electrode) and xiphoid (positive electrode) cartilages; and lead $\mathrm{Z}$ was placed over the dorsal spinous process of $\mathrm{T} 7$ (negative electrode) and on the ventral aspect of the sternum (positive electrode). Three indexes were measured on the vector magnitude: duration in milliseconds (ms) of the filtered QRS complex, duration (ms) of the terminal $40 \mathrm{~ms}$ of the QRS complex (below $40 \mu \mathrm{V}$ ) (LAS40), and the root mean square voltages of the last $40 \mathrm{~ms}$ of the QRS complex (RMS40).

\section{RESULTS}

Echocardiographic evaluation of dogs during the induction of doxorubicin cardiomyopathy showed a reduction in the fractional shortening $(18 \pm 4 \%)$ and ejection fraction $(37 \pm 8 \%)$, as well as an increase in the internal diameter of cardiac chambers in every animal.

As shown in Table 1, animal 1 presented an increase in the duration of the filtered QRS and of the low amplitude signals in the last $40 \mathrm{~ms}$ of the QRS complex (LAS40). Animal 2 also showed an increased filtered QRS duration and the presence of low amplitude signals, causing a reduction in the root mean square voltage of the last 40ms of the QRS complex (RMS40). These two electrocardiographic alterations characterize the occurrence of a late potential.

The animals in which late potentials were detected presented died suddenly a few days later.

\section{DISCUSSION}

In the present study, good quality tracings were obtained by the HRECG technique. Factors that might compromise the electrocardiographic

${ }^{5}$ Digital Holter System CSK 540D - Cardio Sistemas Com. Ind. Ltda - São Paulo, Brazil. recordings include muscle tremors, a heart rate above $140 \mathrm{bpm}$, and slurring of the ST segment. The last two factors impair the identification of the final part of the QRS complex, whose correct identification is necessary for the establishment of the measured indexes (QRS, LAS40, and RMS40) (Calvert, 1998). No alterations that would compromise the HRECG analysis were observed.

Table 1. Results of high-resolution electrocardiography obtained for the seven dogs with doxorubicin-induced cardiomyopathy

\begin{tabular}{cccc}
\hline DOG & $\begin{array}{c}\text { QRS } \\
(\mathrm{ms})\end{array}$ & $\begin{array}{c}\text { LAS40 } \\
(\mathrm{ms})\end{array}$ & $\begin{array}{c}\text { RMS40 } \\
(\mu \mathrm{V})\end{array}$ \\
\hline 1 & 79 & 32 & 150 \\
2 & 89 & 12 & 90 \\
3 & 74 & 15 & 235 \\
4 & 75 & 18 & 135 \\
5 & 67 & 15 & 287 \\
6 & 71 & 17 & 203 \\
7 & 72 & 22 & 201 \\
\hline
\end{tabular}

LAS40: duration of the low amplitude signals in the last 40ms of the QRS complex;

RMS40: root mean square voltage of the last $40 \mathrm{~ms}$ of the QRS complex.

The intravenous administration of doxorubicin was found to be efficient in the induction of cardiomyopathy. The cardiotoxic effects of the drug resemble the alterations reported for the progression of idiopathic dilated cardiomyopathy (Silva e Camacho, 2005; Pereira Neto et al., 2006). Thus, the experimental model of doxorubicin-induced cardiomyopathy can be used to evaluate the occurrence of late potentials in the presence of cardiomyopathy. Echocardiography was an efficient diagnostic technique in the evaluation of dogs during the induction of cardiomyopathy. The assessment of cardiac activity during systole and diastole, the internal anatomy of the heart, its movement, contraction, and ejection capacity can be accomplished with this technique (Kienle and Thomas, 1995).

Coronary artery disease is a condition that concentrates the largest number of publications associating late potentials and ventricular arrhythmias in humans (Moffa, 2000). According to this author, late potentials originate from small areas of the myocardium at the peripheral infarcted muscle where normal muscle fibers are imbricated with fibrous tissue, leading to delayed 
conduction. In the present study, the two animals that presented late potentials showed sudden cardiac death. The term sudden cardiac death was defined by Dennes et al. (1983) as an unexpected death due to cardiac causes and characterized by acute loss of consciousness within one hour after symptom onset in patients with either known or unknown heart disease. The most frequent causes of sudden cardiac death are ventricular arrhythmias including ventricular tachycardia and ventricular fibrillation. The present results agree with Berg et al. (1995) who described an episode of sudden death in dogs chronically receiving doxorubicin for the treatment of osteosarcoma.

The occurrence of late potentials in two animals suggests that a reentry mechanism was responsible for the genesis of arrhythmia. Late potentials are noninvasive markers of the anatomic reentry substrate. These potentials represent a delayed depolarization that corresponds to true latent arrhythmogenic ventricular electrical activity (Kienle and Thomas, 1995). The reentry mechanism explains most premature contractions and paroxystic and non-paroxystic tachycardias.

The other animals showed no clinical evolution compatible with the occurrence of sustained ventricular tachycardia or even sudden death. Two dogs developed refractory congestive heart failure. These animals manifested severe pulmonary edema and died within a few days. The other animals remained asymptomatic until the end of the observation period (60 days).

In humans with nonischemic cardiomyopathy, the high-resolution electrocardiogram identified late potentials in $83 \%$ of the patients with history of sustained ventricular tachycardia (Moffa, 2000). Similar reports have not been published in veterinary medicine literature.

Calvert (1998) has established normal values of HRECG in Doberman pinschers. According to his findings, to be considered within the normal range, the filtered QRS complex should be shorter than $75 \mathrm{~ms}$, the duration of LAS40 should be shorter than $26 \mathrm{~ms}$, and the RMS40 voltage should be greater than $117 \mu \mathrm{V}$.

The advances in antiarrhythmic therapy have led to a marked increase in the survival of patients prone to develop sustained ventricular tachycardia. Therefore, HRECG may be useful in the early identification of patients which are at risk of developing malignant ventricular arrhythmias.

\section{CONCLUSION}

HRECG permitted the identification of dogs under doxorubicin-induced cardiomyopathy that were at high risk of developing ventricular tachycardia and sudden cardiac death, demonstrating that it is an efficient diagnostic method.

\section{REFERENCES}

BREITHARDT, G. Standarts for analysis of ventricular late potencials using high resolution signal averaged electrocadiography. Eur. Heart J., v.12, p.473- 478, 1991.

CALVERT, C.A. High resolution electrocardiography. In: GOODWIN, J. (Ed). Advances in cardiovascular diagnostic and therapy. Philadelphia: W.B. Saunders, 1998. p.1429-1447.

DENES, P.; SANTARELLI, P.; HAUSER, R.G. et al. Quantitative analysis of the high-frequency components of the terminal portion of the body surfacy QRS in normal subjects and in patients with ventricular tachycardia. Circulation, v.647, p.1129-1138, 1983.

HATÉM, D.M.; GUS, M.; HALPERIN, C. Aplicações clínicas da eletrocardiografia de alta resolução. Arq. Bras. Cardiol., v.60, p.357-360, 1993.

JACOBS, G.J. Cardiomyopathies: their classification and pathophysiologic features. Vet. Med., v.91, p.436-444, 1996.

KIENLE, R.D.; THOMAS, W.P. Echocardiography. In: NYLAND, T.; MATOON, J.S. (Eds). Veterinary diagnostic ultrasound. Philadelphia: W.B Saunders, 1995. p.198-255.

MEURS, K.M. Primary myocardial disease in the dogs. In: ETTINGER, S.J.; FELDMAN, E.C. Textbook of veterinary internal medicine. 6.ed. Philadelphia: W.B. Saunders, 2005. p.10771082. 
MOFFA, P.J. Eletrocardiografia de alta resolução. In: FRIEDMANN, A.A.; GRINDLER, J. (Ed). Eletrocardiografia básica. São Paulo: Sarvier, 2000. p.123-128.

OLSON, H.M.; CAPEN, C.C. Subactue cardiotoxocity of adriamycin in the rat: biochemical and ultrastructural investigations. Lab. Invest., v.37, p.386-394, 1977.

PEREIRA NETO, G.B.; ANDRADE, M.G.; CAMACHO, A.A. Holter electrocardiography in dogs showing doxorubicin-induced dilated cardiomyopathy. Arq. Bras. Med. Vet. Zootec., v.58, p.1037-1042, 2006.

SILVA, C.E.V.; CAMACHO, A.A. Alterações ecocardiográficas em cães sob tratamento prolongado com doxorrubicina. Arq. Bras. Med. Vet. Zootec., v.57, p.300-306, 2005.

STRICKLAND, K.N. Advances in antiarrhythmic therapy. In: GOODWIN, J. Advances in cardiovascular diagnostic and therapy. Philadelphia: W.B. Saunders, 1998. p.1515-1545. 